\title{
In Defense of International Rules on the Use of Force
}

\author{
Oscar Schachter $\dagger$
}

The Nuremberg principles that emerged at the end of World War II were hailed as a momentous advance toward an effective rule of law in international society. They affirmed in unmistakable terms that aggressive war is illegal and that persons responsible for such wars are guilty of an international crime. These principles were first expressed in the London agreement of 1945, by which the leading victorious allied states-the United States, the Soviet Union, Great Britain, and France-established the International Military Tribunal to try the leaders of Nazi Germany for their role in planning and waging the war. ${ }^{1}$ An eleven-power agreement established a similar international tribunal in Tokyo to try Japanese officials and military leaders for their part in the Far Eastern war. ${ }^{2}$ Both tribunals convicted a number of defendants and imposed sentences of death or long imprisonment. ${ }^{3}$ The legal principles

$\dagger$ Hamilton Fish Professor Emeritus of International Law and Diplomacy, Columbia University; Member, Institut de Droit International.

This article has been written in honor of Professor Bernard Meltzer on his attainment of emeritus status at The University of Chicago. Professor Meltzer served on the staff of the Chief Prosecutor at the Nuremberg Trial of the Nazi war criminals. In an article on Nuremberg written for this Review in 1947, he reflected on the problem of outlawing war in a world where force had a dominating role. It seems fitting to take this as the theme of this article.

This also gives me a welcome opportunity to acknowledge my debt to Professor Meltzer for his guidance and stimulation when I served with him in the State Department in 194243. It was not only his intellectual energy and quickness of mind that impressed me then. I found his combination of sagacity, zest, and idealism to be admirable, especially in combating bureaucratic apathy and resistance. I was glad to see that a recent scholarly work, The Abandonment of the Jews, by David Wyman, has brought some of this to public light.

${ }^{1}$ Agreement for the Prosecution and Punishment of the Major War Criminals of the European Axis (The London Agreement), August 8, 1945, 59 Stat. 1544, 3 Bevans 1238, 82 U.N.T.S. 279, rectified by Protocol of October 6, 1945, 59 Stat. 1586, 3 Bevans 1286.

2 U.S. Dep't of State, Pub. No. 2675, The Charter of the International Military Tribunal for the Far EASt (1946).

3 See Judgment of the International Military Tribunal at Nuremberg, 1 TRLAL of THE Major War Criminals Before the International Military Tribunal 365-66 (1947) [hereinafter cited as Judgment]; Telford Tayor, The Nuremberg War Crimes Trials 241, 332 (Int'l Conciliation No. 450, 1949). Taylor's survey also includes an account of the 12 Nuremberg trials conducted by the U.S. military government in Germany under the authority of an Allied Control Council law. On the proceedings of the Tokyo trials, see Solis HoRwitz, THE Tokyo Trial 475, 572 (Int'l Conciliation No. 465, 1950). 
they applied became known as the Nuremberg principles.

In a unanimous resolution adopted in 1946, the United Nations General Assembly affirmed the Nuremberg principles as existing in international law. ${ }^{4}$ No government then or since has expressed dissent from these principles, and it is almost inconceivable today that any government would challenge them.

Yet the facts of international life seem to make a mockery of the Nuremberg principles. Wars and invasions occur with alarming frequency; armed force is used in many contexts-overthrowing governments, capturing territory, avenging old wrongs, or coercing favorable settlement of disputes. Veiled or open threats of violence provide undercurrents to all interactions between states. States spend huge sums on munitions; the looming threat of nuclear holocaust endangers all states. Our political and social systems are deeply influenced by the fear of war and a conviction that nothing can be done to oust armed force as the final arbiter in international conflicts.

These facts of life stand in striking contrast to the hopes implicit in the Nuremberg judgments. Not surprisingly, people generally are skeptical that legal rules can restrain violent acts. At the same time, awareness of the horrors of war and its threat to human survival compels us to seek ways of combating the near anarchy of international society.

This essay examines current efforts in that direction that are of particular interest for international lawyers and governments. The questions I discuss were raised or implied in the Nuremberg cases, but they remain important today in light of increasing government employment of armed force to achieve a multiplicity of goals.

The article is divided into the following four parts:

I. Rules on Force and Rule-Skepticism

II. Implied Conditions and Changed Circumstances

III. Necessary Self-Defense

IV. Justification of Force for Higher Ends

\section{Rules on Force and Rule-Skepticism}

A. The Nuremberg Trials

A central issue in the Nuremberg trials was whether aggressive war had been illegal and criminal under international law prior to

4 G.A. Res. 95, U.N. Doc. A/64, at 188 (1946). 
1945..$^{5}$ Counsel for the defendants claimed that the principles laid down in the four-power London agreement had not previously been customary international law, and that to apply them would violate the basic juridical postulate prohibiting punishment of a crime in the absence of a pre-existing law. "Nullum crimen sine lege, nulla poena sine lege."

The tribunal rejected defense counsel's contention, citing in particular the General Treaty for the Renunciation of War as an Instrument of National Policy (the Kellogg-Briand Pact) of 1928, which in 1939 had 63 parties including Germany. ${ }^{7}$ That treaty condemned recourse to war for the solution of international disputes. ${ }^{8}$ The tribunal also referred to other international declarations (including a resolution of the League of Nations, a declaration of a Pan-American Conference, a protocol on dispute settlement not yet in force, and a draft treaty on mutual assistance) to support the conclusion that aggressive war had long been branded as criminal by the international community. ${ }^{9}$ These treaty commitments, the tribunal declared, necessarily postulated the illegality of aggressive war and the criminality of its promoters. In drawing this implication, the tribunal reasoned that wars of aggression were illegal under general customary international law and not simply a violation of the treaty in question. ${ }^{10}$ The judgment discussed the role of state practices in developing international law and, particularly, noted how the Hague Conventions on the laws of war had grown out of and, in turn, become accepted as customary law. ${ }^{11}$

The tribunal considered it important to establish this proposition, which would move the issue beyond specific treaty terms and elevate the illegality of aggression to a universal rule. ${ }^{12}$ It also seems plausible that the tribunal found it desirable to emphasize customary law to rebut defense counsel's contention that aggres-

S See Schachter, The Right of States to Use Armed Force, 82 Mrch. L. REv. 1620, 162833 (1984).

- Judgment, supra note 3 , at 219.

IId.

Bellogg-Briand Pact, August 27, 1928, 46 Stat. 2343, T.S. No. 796, 94 L.N.T.S. 57.

- Judgment, supra note 3, at 221-22.

10 Id. at 220-21 ("The law of war is to be found not only in treaties, but in the customs and practices of states which gradually obtained universal recognition. . . . [I]n many cases treaties do no more than express and define for more accurate reference the principles of law already existing.").

11 Id. at 253-54.

12 The tribunal's emphasis on customary law is also underlined by its rather cursory consideration of the London agreement provision stating that crimes against peace included wars in violations of international agreements. $I d$. at 219 . While it found this provision relevant to Germany's treaty violations, it did not make this the main ground of the judgment. 
sion could not be a standard of criminal liability because it had not been defined in any international document. ${ }^{13}$ By relying on customary law, the tribunal could draw an analogy to the historic development of the criminal law. Common crimes such as murder, robbery, and rape were punished by societies long before they were defined in general terms. ${ }^{14}$

In the same sense, the tribunal found it unnecessary to define aggression. It set forth the historical facts and deemed them proof enough that the defendants planned, initiated, and waged aggressive war under any conceivable definition of aggression..$^{15}$ Moreover, the absence of a definition did not mean that the accused had no idea they were doing wrong. The tribunal was convinced that the Nazi leaders were aware of the Kellogg-Briand Pact and of other agreements labeling aggressive war as illegal. On that premise it would have been unreasonable to conclude that the defendants were being prosecuted for an offense that was being applied retroactively against them, for the rule against retroactivity was intended to protect persons who could not have known of their guilt.

\section{B. The Gap Between Rules and State Practice}

Of particular interest in the present context is that the tribunal did not find it necessary to examine any specific state conduct in order to establish customary practice: it considered the several declarations already noted to be evidence enough of customary law. ${ }^{16}$ It did not ask whether those declarations accorded with the "constant and uniform practice" of states which international lawyers consider an essential constitutive element of customary law. ${ }^{17}$ It did not compare practice and preaching. It took the declarations as the opinio juris communis of international society without trying to discover the "real" attitudes of states.

A perceptive observer such as Professor Meltzer was bound to be troubled by this. Writing in this law review ${ }^{18}$ soon after the $\mathrm{Nu}-$

${ }^{13}$ Id. at $219-22$.

14 In a statement to the U.N. General Assembly's Legal Committee, the Netherlands judge who sat in the Tokyo trial said that "as easily as [a judge] operates with the crime of 'murder' he might operate with the crime of 'aggression.' "Roling, On Aggression, On International Criminal Law, On International Criminal Jurisdiction-I, 2 NEDERLANDS TIJDSCHRIFT VOOR INTERNATIONAAL REChT 167, 169 (1955).

is Judgment, supra note 3 , at 186-216.

${ }^{16} \mathrm{Id}$. at $220-22$.

${ }_{17}$ See Right of Passage over Indian Territory (Port. v. India), 1960 I.C.J. 4, 38; North Sea Continental Shelf (W. Ger. v. Den.), 1969 I.C.J. 4, 41-45 (especially paragraphs 74-77).

${ }^{18}$ Meltzer, A Note on Some Aspects of the Nuremberg Debate, 14 U. CHI. L. REv. 455 
remberg judgment, he contrasted the declarations and realities. $\mathrm{He}$ commented that "[w]ar in Europe had been almost as natural a relation as peace," reflecting a "tradition of aggression and its moral acceptance."19 This led him to ask whether condemning aggression as a violation of existing law meant positing "order and morality where only anarchy and amorality prevail." 20 Without referring to the international law requirement of uniform practice, he posed the underlying question of whether verbal declarations might not be mistaken for meaningful standards that governed actual conduct. ${ }^{21}$ But after raising these issues, Meltzer concluded by supporting the tribunal's reliance on "the most solemn, widespread and unequivocal condemnations of aggression."22 "When a standard of conduct has been embodied and repeatedly reaffirmed, in the most solemn and unequivocal international formulations, it would be a dangerous invitation to anarchy to disavow it on the basis of doubtful conjectures as to the 'real' state of international psychology."23

Professor Meltzer characteristically chose his words carefully. $\mathrm{He}$ is surely right to counsel against disavowing states' declarations against aggression because of "doubtful conjectures" about "international psychology." But this does not fully answer his own question about meaningful standards, nor does it meet the basic doctrinal point that practices rather than mere words become customary law rules. These issues still haunt us. They arise whenever states use armed force in circumstances inconsistent with the present law as set forth in the U.N. Charter and the authoritative definition of aggression adopted by consensus in the U.N. General Assembly of $1974 .{ }^{24}$

It is not difficult to think of recent cases in which the rule against the use of force was probably violated. Consider some of the recent hostilities in: Afghanistan, Angola, Cambodia, Chad, Falkland Islands, Grenada, Iraq-Iran, Lebanon, Mozambique, Nicaragua, Vietnam. In each of these places, foreign states employed

(1947).

10 Id. at 459.

$20 \mathrm{Id}$.

21 Id.

22 Id.

2s Id. at 460 .

24 G.A. Res. 3314, 29 U.N. GAOR Supp. (No. 31) at 142, U.N. Doc. A/9631 (1974) [hereinafter cited as Aggression Resolution], reprinted in part in L. HENKIN, R. PuGH, O. Schachter \& H. Smit, International LaW: Cases and Materials 915-18 (2d ed. 1980) [hereinafter cited as CASEBOoK]. 
military force for one reason or another, generally claiming legal justification in the language of the U.N. Charter. ${ }^{25}$ The most frequent stated ground was self-defense, either individual or "collective" (i.e., on behalf of a state attacked by others). In some cases, a government or head of state facing internal or external opposition was said to have requested the military intervention. ${ }^{26}$ The state supplying aid maintained that the force was not used "against the territorial integrity or political independence" of the requesting state or in any other manner contrary to the principles of the U.N. Charter. ${ }^{27}$

The quality of these justifications varies. The U.S. has tended to provide fuller and more sophisticated legal justifications than most other countries, probably because Congress and important sectors of public opinion are concerned about the legitimacy of American action..$^{28}$ For example, the U.S. State Department offered three justifications for the U.S. invasion of Grenada on October 25, 1983: (1) the Governor-General of Grenada explicitly requested U.S. military assistance; (2) the Organisation of Eastern Caribbean States, composed of Grenada and its island neighbors, requested U.S. help in abating what it perceived as a threat to its member nations' security; and (3) a state has a right under customary international law to protect its nationals facing imminent danger of death in other countries. ${ }^{29}$

Many countries, in contrast, have limited their claims to brief and general phrases of Charter terminology and their own version of the relevant facts. When the Soviet Union sent troops into Czechoslovakia in 1968, for example, it asserted that this action came in response to that government's "urgent" request for assistance. ${ }^{30}$ After this justification had been repudiated repeatedly by the Czechoslovak National Assembly, and was specifically disavowed in a message from the Czechoslovak Foreign Ministry to

25 U.N. Charter arts. $2(4), 51 \& 42$.

${ }^{26}$ See infra text accompanying notes 29-30.

${ }^{27}$ U.N. Charter art. 2, para. 4 reads as follows: "All Members shall refrain in their international relations from the threat or use of force against the territorial integrity or political independence of any state, or in any other manner inconsistent with the Purposes of the United Nations."

${ }^{28}$ As one observer stated after the U.S. action in Grenada, "The American people will not tolerate continuous illegal conduct." Remarks by Senator Nunn, University of Georgia Law Day (April 14, 1984).

${ }^{28}$ Letter from Davis P. Robinson, Legal Adviser, U.S. Dep't of State, to Professor Edward Gordon (Feb. 10, 1984) (outlining U.S. legal position concerning Grenada), reprinted in John Norton Moore, Law and the Grenada Mission 125-29 app. (1984).

${ }^{30} 7$ I.L.M. 1283 (1968). 
the Security Council, ${ }^{31}$ the Soviet Union relied instead on a more general claim of self-defense under the U.N. Charter. ${ }^{32}$ Not surprisingly, most outsiders view many of these legal contentions skeptically, primarily because states, in substantiating their claims, frequently seem to cite carefully chosen, if not fabricated, sets of facts. Thus, the legal justifications offered by states are often perceived as rationalizations contrived after the decision to intervene had been made.

\section{The Paradox of Rules}

It is a small step from these skeptical reactions to the conclusion that legal principles mean little in practice. At the least, the law in reality differs from the law on the books. The very fact that states can advance a legal argument for every use of force is a ground for skepticism. It brings to mind a well-known "paradox" of Wittgenstein (which I amend slightly): "No course of action can be determined by a rule because every course of action can be made out to conform with every rule." 33 This paradox seems especially pertinent in view of the absence of a compulsory system of adjudication. The ostensible freedom of states to define the rules for themselves, particularly where the rules are highly general and strong political motives govern behavior, builds into a strong case for rule-skepticism. Hence many are inclined to agree with Raymond Aron that international society is an "anarchical order of power" in which might makes right. ${ }^{34}$

1. The Core Meaning of the Rules. Strong as the case for rule-skepticism appears to be, it unduly simplifies the complex interactions between norms and state conduct. To begin with, it is an exaggeration to consider the Charter rules so indeterminate and malleable that governments can always make out a plausible case for the legality of their actions. Of course, like all general rules, they give rise to problems of interpretation in their application to concrete situations. They are not free of ambiguity and they may call for factual appraisals as to which reasonable persons can differ.

s1 7 I.L.M. 1294, 1305, 1313 (1968); U.N. Doc. S/P.V.1441, If 31, 34 (Provisional Record) (1968).

${ }^{32}$ U.N. Doc. S/P.V.1441, ชิ 90, 93 (Provisional Record). To justify its action, the Soviet Union also announced the "Brezhnev Doctrine," which proclaims that socialist states have a right to intervene in other socialist states where necessary to meet threats to socialism. 7 I.L.M. 1323 (1968). The doctrine has not been reasserted since that time.

33 Ludwig Wittgenstein, PhLosophical Investigations 201 (1953).

3* Aron, The Anarchical Order of Power, in Conditions of Wordd ORDER 25 (S. Hoffman ed. 1968). 
One cannot expect them to be applied by computers. Nevertheless, the rules have a core meaning that governments and legal experts generally accept. Thus it is perfectly clear that states may not invade others for gain or domination, a principle affirmed in the judgments of the Nuremberg and Tokyo trials.

The present rules go beyond this: states may no longer take up arms to avenge past injustices or to vindicate legal rights. ${ }^{35}$ This is widely agreed, even though some contemporary writers argue for broader rights to use force ${ }^{36}$ of course, states have the unquestioned right to use armed force in response to an armed attack on them. ${ }^{37}$ There is some disagreement whether the requirement of an armed attack has superseded the somewhat broader customary law right of defense against an imminent attack..$^{38}$ However, this difference is narrow if "imminent attack" is strictly construed.

Self-defense must not only be necessary but also proportional to the offense in its extent, manner, and goal. The criterion of proportionality leaves a broad margin of discretion to a defending state but it also imposes well-understood limits. Thus, it would undoubtedly be disproportionate to bomb cities in response to a frontier raid or to invade and occupy territory of a state because that state has illegally aided insurgents in a civil war.

The law also clearly allows collective self-defense, so that a state may aid a victim of actual aggression. ${ }^{39}$ This right has been invoked by several countries as a legal basis for their armed interventions in civil wars where insurgents have been aided by an outside power. ${ }^{40} \mathrm{~A}$ counter-intervention is permissible against a prior illegal intervention provided it is not disproportionate in manner and extent. ${ }^{41}$ However, difficulties do arise in this context.

${ }^{3 s}$ See Schachter, supra note 5, at 1625-27; The Corfu Channel Case (U.K. v. Albania), 1949 I.C.J. 4, 35.

${ }^{36}$ See, e.g., Julius Stone, Aggression and World ORder 92-134 (1958); A.V. Thomas \& A.J. Thomas, JR., Non-INTERVENTION 208-10 (1956).

37 U.N. Charter art. 51.

${ }^{38}$ See infra note 89 and accompanying text (discussing Israel-Iraq conflict).

${ }^{39}$ See, e.g., U.N. ChaRTER art. 51. There are, however, several possible interpretations of the scope of permissible collective self-defense. The NATO and Warsaw Pacts and the InterAmerican Rio Treaty are premised on the right of any party to the treaty to come to the aid of an attacked state whether or not the acting party faces a threat to its security. See Schwebel, Aggression, Intervention and Self Defence in Modern International Law, 136 RECUEIL des Cours 411, 478-83 (1972).

10 Two recent examples are the Soviet Union's claim in regard to its actions in Afghanistan and the United States' claim with respect to its activities in Nicaragua.

4 See Resolution of Institut de Droit International on the Principle of Non-Intervention in Civil Wars, 56 ANN. INST. DR. INT'L 544, 549 (1975) [hereinafter cited as Resolution on Non-Intervention]. John Stuart Mill made the point in 1859: "Intervention to enforce 
The facts are often disputed and sometimes the claim of a prior illegal intervention has lacked credible evidence. ${ }^{42}$ In still other cases, the counter-intervention has been clearly disproportionate. ${ }^{43}$ Yet the problems of weighing facts should not be exaggerated: they make it difficult to apply the agreed rules but they do not mean that the rules lack content.

In short, it is unwarranted to view the Charter rules as entirely "open-textured," allowing states unlimited latitude to interpret them. The general contours of the rules are clear.

2. Third-Party Determinations. A skeptic may respond that it hardly matters whether the rules have a core meaning in the absence of compulsory third-party adjudication of unilateral interpretations. As the Nuremberg tribunal declared in its judgment: "whether action taken under the claim of self-defense was in fact aggressive or defensive must ultimately be subject to investigation or adjudication if international law is ever to be enforced."44 The point has often been made. It is incompatible with the concept of law that an entity subject to the law should have the final authority to determine whether a legal rule applies to it.

One answer to this line of argument is that third-party judgments are in fact made; self-serving unilateral justifications are not always accepted by the international community. Whenever a state has recourse to armed force outside of its territory, the legitimacy of that action is appraised by other states, organizations, non-governmental groups, and individuals. The more formal and prominent judgments issue from the international political organs that deal with issues of peace and security, notably the U.N. Security Council and General Assembly. These decisions generally command state attention. They are more likely to persuade where the facts are reasonably clear and critical resolutions receive substantial majority support, especially where the majority includes governments allied to or generally sympathetic to the impugned states. $^{45}$

non-intervention is always rightful, always moral, if not always prudent." J.S. Mill, A Few Words on Non-Intervention, in 21 Collected Works of John Stuart Mill 109, 123 (J. Robson ed. 1984).

42 See, e.g., supra notes 30-32 and accompanying text (discussing the Soviet invasion of Czechoslovakia).

43 For example, invasions by Vietnam of Cambodia, by Syria of Lebanon, and by Libya of Chad.

"1 Judgment, supra note 3, at 208.

15 See Schachter, supra note 5, at 1622-23; G.A. Res. 37/37, 37 U.N. GAOR Supp. (No. 51) at 25, U.N. Doc. A/37/P.V. 82 (1983) (condemnation of the Soviet Union for its invasion of Afghanistan); G.A. Res. 38, 38 U.N. GAOR Supp. (No. 47) at 19, U.N. Doc. A/38/P.V. 43 
But decisions of the U.N. political bodies-or their failure to decide-should not be considered definitive in every case. These are political, not judicial bodies. Their members are free to pass on the issues of legality for whatever reasons they deem appropriate. Political pressures and "mechanical" bloc voting may detract from the persuasive authority of those decisions. Thus, the collective judgments may lack the respect and authority normally associated with judicial tribunals. Moreover, the judgments of U.N. political organs are not legally binding except in the rare instances where they form part of a mandatory decision of the Security Council. ${ }^{46}$ Still, they remain an important means for the international community to express its collective opinion of state claims.

Criticism from non-governmental groups may be even more significant-not because these groups voice an amorphous world opinion but rather because their particular composition and concerns lend significance to their judgment. Recall, for example, the criticism by non-Soviet bloc communist parties of the Soviet uses of force in Czechoslovakia in 1968 and in Afghanistan in 1981. ${ }^{47}$ The fact that these parties previously had consistently supported Soviet political positions gave more weight to their subsequent opposition.

Another important category of unofficial judgments is that of the international lawyers, especially their academic component. This is not mere professional conceit. Because of the paucity of case law and the politicized character of governmental positions, the expert opinions of legal scholars and their professional bodies command attention and respect. The views of these experts are persuasive when they are expressed in reasoned discourse supported by authority and principle. Moreover, since international lawyers come from many countries and have diverse approaches, their opinions have added weight when they coincide and reinforce each other. ${ }^{48}$

3. The Political Costs to the Targets of International Censure. The skeptic may concede these points but still persist in his

(1983) (condemnation of the U.S. for its invasion of Grenada). For a critical comment on the U.N. resolution and arguments for the U.S. position on Grenada, see J. Moore, supra note 29. On the unanimous condemnation of Iran for its part in the seizure of American diplomatic personnel in Tehran, see Security Council Res. 457, U.N. Doc. S/INF/35 (1979).

4 See U.N. Charter arts. 12, 14.

47 See, e.g., 7 I.L.M. 1285 (1968) (the Czechoslovak Communist Party condemns the Soviet Union).

48 See Schachter, The Invisible College of International Lawyers, 72 Nw. U.L. REv. 217 (1977); see also Terry Nardin, Law, Morality aNd the Relations of States 173-77 (1983). 
doubts. He can argue that without international enforcement, censure has no impact on state actions: it remains merely rhetorical condemnation without sanctions. Law must be more than aspiration or ideal. However, states do in fact strongly object to such condemnation and will make determined efforts to forestall censure by the U.N. ${ }^{49}$ That they do so shows that a condemnation of illegality by an international organ, even if not binding, is regarded as detrimental, imposing political costs on the offender. ${ }^{50}$ Such condemnations by large majorities have contributed to transforming the image of a great power from a champion of national independence to that of a threat to the sovereignty of weaker states. One cannot doubt that this transformation of image has negative political consequences for the state criticized.

Thus, we can plausibly infer that governments consider the possibility of such censure when they face a decision to use force. That this frequently happens is suggested by the fact that for virtually every use of force, the responsible state has sought to justify it under the accepted Charter rules. Though such legal justification may merely rationalize a decision made for reasons of interest or power, the felt need of governments to advance a legal argument is itself a fact of some consequence. The fact that their legal arguments may be rationalizations does not mean they are without influence. The claims, however hypocritical, have a political object; they must be believed to serve that purpose and to be credible they must appear to influence conduct. Hence governments have good reason to keep from doing what cannot be justified.

Of course these considerations do not add up to an iron law of rule-governed conduct. States may still decide to violate the law and face a loss of credibility and other negative consequences. In most cases, they need not fear that effective collective sanctions will be imposed by the U.N. or other groups of states. But they are nevertheless aware that the illicit use of force is not cost-free. Insofar as that perception exists, it has an impact on state conduct. The legal restraints thereby acquire a measure of efficacy; they are

10 See Thomas Franck, Nation Against Nation chs. 10 \& 11 (1985).

so "The ability of the United States to exert its influence in world affairs in furtherance of the humane and democratic values we most deeply believe in will be determined in the long run by the perceived legitimacy of our imposing national power, as well as by that power itself." Gordon, Bilder, Rovine \& Wallace, International Law and The United States Action in Grenada: A Report, 18 InT'L LAw. 331, 332 (1984) [hereinafter cited as Grenada Report]; see also Louis Henkin, How Nations Behave 314-39 (2d ed. 1979); Christopher, Introduction, to American Hostages In Iran 10-13 (P. Kreisberg ed. 1985); Cutler, The Right to Intervene, 64 Foreign Apr. 96, 96-97 (1985). 
not simply aspirations or paper rules.

4. The Basic Need for Rules. We are left then with the political scientists and journalists who remain cynical about attempts "to suppress the chaotic and dangerous aspirations of governments in the international field by the acceptance of some system of legal rules and restraints." Their basic hypothesis is that states act out of national interest, constrained, in the last analysis, only by power. Not only apparent violations of rules but even compliance verifies their view, since compliance can also be motivated by the state's perceived national interest. In short, no matter what a state does, it must be acting for reasons of interest, not law.

This line of reasoning begs the questions of whether states consider law-observance generally in their interest and whether that perceived interest occasionally prevails over other interests. This is an empirical matter to which no final answer can be given. However, in considering the reality of rules on force we must not forget that the distinction between illicit and allowable uses of force is essential to every legal system. International society requires it no less than national communities. Charles De Visscher, a past President of the International Court of Justice, stated: "It is not possible at one and the same time to base international relations on the independent existence of States and to concede to each State the sovereign right to take up arms to attack or destroy that independence." 52 The logic of that proposition underlies the common interest in maintaining the restraints on force.

\section{Implied Conditions and Changed Circumstances}

It is one thing to conclude that we need some restraints on force; it is another matter to determine their precise limits. The existing rules cannot be considered necessary in the philosophical sense. They have a contingent character in that they depend on human choices and on the myriad factors conditioning such choices. The rules may be defended as established law, but that does not foreclose demands for change, whether by way of reinterpretation or explicit revision.

Consideration of these demands for change is particularly timely: they are now advanced with increasing frequency and intensity. Proponents of change contend at bottom that recent devel-

s1 See George Kennan, American Diplomacy 1900-1950, at 94 (1951).

52 Charles de Visscher, Theory and Reality in Public International Law 294 (Corbett trans. $2 d$ ed. 1968). 
opments in international relations have significantly altered the conditions on which the restrictive Charter rules were based. We now require new interpretations and new rules, it is argued, to secure minimal order and justice among states. ${ }^{53}$ Significantly, no responsible person proposes abandoning all rules; everyone appears to recognize the need to limit each state's right to take up arms. Generally the revisionists seek to broaden the grounds for recourse to force by individual states without reverting to a Hobbesian state of nature.

\section{A. Dependency of the Charter Rules on the Effectiveness of International Law}

The case for revision rests on a mix of juridical and political arguments. First, the existing rules-of the Charter or general customary law-were premised on the effective functioning of a collective security system. As argued by Julius Stone, one of the earliest and most forceful revisionists, the Charter's renunciation of unilateral force was intended to be "organic[ally] dependen[t] ... on the effective establishment of collective institutions and methods." S4 Since the U.N. collective security system has failed (as shown by the continued frequency of violent international acts), states should be released from their unilateral commitments to eschew force..$^{55}$ The critical policy question is then posed: Why should states abide by the law to their disadvantage when lawless states violate it with impunity?

Although the question is basically political, the legal arguments are relevant. The legislative history of article 2 of the Charter does not support the notion that effective enforcement of collective security was a prerequisite to renouncing the use of force. ${ }^{56}$

s3 [E]xisting legal norms governing the use of armed force reflect past needs and experiences more than current ones. To the extent . . . that reasonable efforts to counter insidious forms of aggression, protect human rights, restore civil order or achieve other legitimate ends do not square with the law[,] . . . perhaps the law needs amendment ...

Grenada Report, supra note 50, at 334.

s6 J. STONE, supra note 36 , at 96.

${ }^{8 s}$ See, e.g., A.V. Thomas \& A.J. Thomas, JR., supra note 36, at 209 ("II]f the collective organization, through a fault in its organizing instrument, leaves a gap where the use of force is necessary but the collective organization is impotent to act, then the legal right to use force must . . . revert back to the members."). But see Grenada Report, supra note 50, at 362 (rejecting this argument on the ground that "a state which has benefited from the Charter cannot belatedly interpose the failure of consideration as a ground for invalidating its consent to be bound by it").

so See, e.g., Djura Nincic, The Problem of Sovereignty in the Charter and in the 
True, the Charter's drafters must have hoped that the Security Council and other relevant U.N. organs would obviate individual recourse to force. But they were realistic enough to recognize that this might not be achieved; that is precisely why they preserved the right of self-defense to respond to armed attack. ${ }^{57}$ Force could meet force but, unless authorized by the Security Council, ${ }^{58}$ force could not answer a non-forcible deprivation of rights. It is hardly plausible to infer from these provisions that the failure to prevent illegal force now allows an individual state to use force freely. No evidence or logical reason supports the assumption that the drafters or the signatory governments intended this radical result. Rather, widespread affirmation of the rules on force as jus cogens, peremptory norms of customary law, ${ }^{58}$ shows that states regard those rules as legally independent of the proper functioning of U.N. organs.

\section{B. Necessity of Force to Safeguard Legal Rights}

The political case for revision includes another argument: if individual force is limited to self-defense, states may have no adequate means of resisting violations of their legal rights. ${ }^{60}$ States often cannot obtain satisfaction through international judicial or political processes, yet they are barred from resorting to force unless they are attacked (or facing imminent danger of attack). ${ }^{61}$

This does not leave states without remedies. Aggrieved states may employ economic and other non-military countermeasures ${ }^{62}$ to

Practice of the United Nations 72, $76-77$ (1970) (guarantees of territorial integrity in article 2(4) were not intended to limit the article's broad prohibition of self-help measures).

s7 U.N. Charter art. 51.

ss Id. arts. 36, 39-42.

${ }^{58}$ See infra note 72.

60 J. STONE, supra note 36 , at 98-101.

61 The Charter does, however, give the Security Council the power to authorize economic sanctions against errant states, including "complete or partial interruption of economic relations and of rail, sea, air, postal, telegraphic, radio, and other means of communication, and the severance of diplomatic relations." U.N. CHARTER art. 41 . This power has been used only infrequently.

62 See Schachter, Self-Help in International Law, 37 J. INT'L AFr. 231 (1984); see also Elizabeth Zoller, Peacetime Unilateral Remedies passim (1984).

It is worth noting that the line between self-help and self-defense has never been entirely clear in customary law. See Hans Kelsen, Principles of International Law 15-17, 58-62 (1952). Prior to the adoption of the U.N. Charter, many writers and governments thought that the right of self-defense applied not only to an actual or threatened physical attack on the state or its instrumentalities but also to violations of legally protected interests. See, e.g., D. NINCIC, supra note 56, at 53 (explaining rationale of the "war as a sanction" theory). Some writers have distinguished self-defense from the wider category of selfhelp by limiting self-defense to responses to violations of rights essential to the security and 
respond to illegal action. ${ }^{63}$ In many cases threats or actions to suspend treaty benefits, fishing rights, imports, immigration, or air transit have succeeded in bringing violations to an end. ${ }^{64}$ Of course these measures do not always redress the wrong. Even powerful countries such as the U.S. have occasionally imposed economic sanctions without conspicuous success. ${ }^{65}$

independence of the state. See Derek W. Bowett, Self-Depence in International Law 270-71 (1958); Bowett, International Law and Economic Coercion, 16 VA. J. INT'L L. 245, $251 \mathrm{n.21}$ (1976). Even when so limited, self-defense would allow forcible responses to a wide range of unlawful and injurious acts by others. The argument of some political theorists that "aggression" must be understood as contrary to "peace-with-rights," see MichaEL WalzEr, JUST AND UNJUST WARS 51 (1977); T. NARDIN, supra note 48, at 284, and that therefore a state using force to defend its rights (even when not attacked) is upholding the common rules of the society of states, has the same flaws as the argument that article 51 of the Charter preserves the "inherent right" of self-defense, which is discussed infra at text accompanying notes 83-86. See William Vincent O'BrIEn, The Conduct of Just and Limited War 38-55, $67-70$ (1981); War, Morality and the Miltrary Propession 232-487 (M.M. Wakin ed. 1979). The theorists' position begs the question since the issue is whether the legal limits on force, including article 51, are part of the common rules. If they are, then one cannot override them in order to safeguard other legal rights.

es States occasionally also use or threaten non-military coercion for political ends such as overthrowing a state's regime or effecting massive changes in its policies. For example, Arab states continue to implement a coercive multi-level boycott designed to destroy the state of Israel. See Joyner, The Transnational Boycott as Economic Coercion in International Law: Policy, Place and Practice, 17 Vand. J. Transnat'L L. 205, 216-20 (1984); Shihata, Destination Embargo of Arab Oil: Its Legality Under International Law, 68 AM. J. INT'L L. 591, 592-93 (1974). Non-military coercion for these purposes is arguably illegal because it is aimed at subordinating the target state's sovereign rights to the will of the coércing state. See Declaration on the Inadmissibility of Intervention in the Domestic Affairs of States, G.A. Res. 2131, 20 U.N. GAOR Annex 3 (Agenda Item 107) at 10, U.N. Doc. A/6220 (1965); Charter of the Organization of American States arts. 15-16; see also Bowett, supra note 62, at 249 (drawing a distinction between allowable and illicit "economic coercion" based on whether the state's motive is economic or political: "once a State is allowed to coerce in the furtherance of its political goals, there is little point even in attempting legally to restrict economic coercion").

Some commentators have gone so far as to contend that economic action of such intensity and magnitude would justify forcible self-defense by the target state, and collective defense by its allies. See Farer, Political and Economic Coercion in Contemporary International Law, 79 AM. J. INT'L L. 405 (1985). I disagree. Even egregious economic aggression, whether or not illegal, does not constitute an armed attack or a use of force in the Charter sense. Allowing forcible reprisal to non-military coercion would broaden the grounds for use of force to an intolerable degree.

se See, generally, G. Hupbauer \& J. Schott, Economic Sanctions Reconsidered (1985).

os When armed conflict broke out between the United Kingdom and Argentina over the Falkland (Malvinas) Islands in 1982, the U.S. first attempted to mediate the dispute. When this failed, it imposed several sanctions against Argentina: "(1) suspension of all military exports and security assistance to Argentina; (2) withholding of certification of Argentine eligibility for military sales; (3) suspension of new Export-Import Bank credits and guarantees; and (4) suspension of Commodity Credit Corporation guarantees." Acevedo, The U.S. Measures Against Argentina Resulting from the Malvinas Conflict, 78 АM. J. INT'L L. 323, 326 (1984). Despite the seriousness of the measures taken, they had no appreci- 
Still, the failure of self-help and international institutions to provide adequate remedies for breaches of legal rights does not impugn the efficacy of the Charter's collective machinery. That machinery does not purport to safeguard legal rights: it was meant to ensure peace and security ${ }^{68}$ Optional judicial machinery is available for legal disputes, and a preamble in the Charter expresses the intent to establish conditions under which justice and respect for law could be maintained. But no language of the Charter supports the view that the failure to safeguard legal rights should nullify the renunciation of individual force. And the consequence of such a view-return to the near anarchy of pre-Charter international society-is too drastic to have been what states contemplated when the Charter was adopted. ${ }^{67}$

\section{Theories of Changed Circumstances}

Two other legal theories support the view that the rules on force have been abrogated by developments in international relations. One is the general requirement of reciprocity. ${ }^{68}$ Widespread violations by states should, in law, release others from the duty to comply. This theory developed by analogy to the right of one treaty party to suspend the treaty between it and a violator for a violation especially affecting that party. ${ }^{69}$ Thus it has been sug-

able effect on the course of the war.

6e See Hans Kelsen, The Law of the United Nations 15-16 (1950).

8z The International Court of Justice had occasion to pass judgment on this issue when Britain used forcible self-help to vindicate its right of passage through the Corfu Channel. The court considered Britain's claim of right unacceptable, observing that a right to use armed force "in the cause of justice" would "be reserved for the most powerful states and might easily lead to perverting the administration of justice itself. . . . [A] policy of force such as [this] has in the past given rise to most serious abuses and . . . cannot, whatever be the defects in international organization, find a place in international law." The Corfu Channel Case (U.K. v. Albania), 1949 I.C.J. 4, 35.

68 Ambassador Jeane Kirkpatrick declared in April, 1984: "The first principle of the law is the equal application of the law. Unilateral compliance with the Charter's principles of nonintervention and non-use of force may make sense in some specific isolated instances, but are hardly a sound basis for either United States policy or for international peace and stability." Address by Ambassador Kirkpatrick to the American Society of International Law 16 (Apr. 1984) (not yet published; copy on file with The University of Chicago Law Review); see also JuLIUS STONE, VisIoNS OF WORLD ORDER 54-55 (1984). For a forceful rebuttal of Kirkpatrick, see Gardner, Sovereignty and Intervention: A Challenge of Law-Making for the Industrialized Democracies, 35 Trialogue 3 (1984).

An interesting discussion of the role of reciprocity in international law may be found in Gottlieb, Relationism: Legal Theory for a Relational Society, 50 U. CHI. L. Rev. 567 (1983).

69 See Vienna Convention on the Law of Treaties, done on May 23, 1969, art. 60, U.N. Doc. A/CONF. 39/27 (entered into force Jan. 27, 1980) [hereinafter cited as Vienna Convention]. Apart from the right of suspension, a party has the right to refuse to perform an 
gested that serious violations of article 2(4) by the Soviet Union would entitle the United States, if it were especially affected, to suspend its obligations to the U.S.S.R. ${ }^{70}$ An even broader contention is that Charter breaches have so radically changed the position of all states that any party may now invoke those violations as a ground for suspending its obligations. ${ }^{71}$ Although these legal principles (contained in the Vienna Convention on the Law of Treaties) cannot be denied, their application to these issues is by no means clear. Significantly, no state has invoked another state's breach of article 2(4) as a legal reason to abrogate the Charter rules. And as we noted, article 2(4) is the exemplary case of a peremptory norm (jus cogens). ${ }^{22}$ Moreover, the Charter stipulates that its obligations prevail over those of any other agreement. ${ }^{33}$ Theoretically the parties to the Charter may bring it to an end but obviously no present disposition exists to do that.

The Charter provides for legal responses to a breach of article 2(4) - most importantly for the right of self-defense in case of an armed attack. ${ }^{74}$ If self-defense is not permissible under the circum-

obligation corresponding to the obligation violated by the other party. The applicable customary law principle is known as inadimplenti non est adimplendum. See ZoLLER, supra note 62 , at $14-27$.

30 See Kirkpatrick, supra note 68, at 17 ("We cannot permit . . . ourselves to be bound to unilateral renunciation of rights which do in fact exist under the Charter.").

For a political argument to the same effect, see Norman Podhoretz, The Present DanGER 39-42, 96-101 (1980). Eugene Rostow concludes that in view of Soviet and other violations of article 2(4), it is impossible to determine whether that article "is an operative legal norm." Rostow, The Legality of the International Use of Force by and from States, 10 YALE J. INT'L L. 286, 290 (1985). For the contrary U.S. State Department position, see Memorandum of R.B. Owen, Legal Adviser of the State Department, quoted in Nash, Contemporary Practice of the United States Relating to International Law, 74 AM. J. INT'L L. 418, 418-20 (1980).

7 See Vienna Convention, supra note 69, art. 60, para. 2(c). This provision in the Vienna Convention is a carefully circumscribed codification of the customary law doctrine of rebus sic stantibus, the principle that treaty obligations may "terminate when a change occurs in those circumstances which existed at the time of the conclusion of the treaty and whose continuance formed, according to the intention or wills of the parties, a condition of the continuing validity of the treaty." Hill, The Doctrine of "Rebus Sic Stantibus" in International Law, U. Mo. STUD., July 1, 1934, at 8; see also L. HzNkin, supra note 50, at 137-38; cf. U.C.C. \$ 2-615 (1978) (codifying the common-law contract doctrine of frustration or commercial impracticability).

${ }^{2}$ The United States has taken the legal position that article $2(4)$ is a peremptory norm from which no derogation by treaty is permitted. See Memorandum of R.B. Owen, supra note 70 , at $418-20$.

73 U.N. ChARTER art. 103.

"I.N. Charter art. 51 reads:

Nothing in the present Charter shall impair the inherent right of individual or collective self-defence if an armed attack occurs against a Member of the United Nations, until the Security Council has taken measures necessary to maintain international 
stances, an injured state (or indeed any state) may bring the violation to the attention of the Security Council or the General Assembly. ${ }^{75} \mathrm{Or}$, the International Court of Justice may be seized of the case if a jurisdictional basis is available under its statute. That these remedies may not effectively redress the violation evidences the system's weakness. But a legal system's failure to prevent or punish wrongs by some entities does not entitle all the others to violate a basic obligation.

In stating this conclusion, I must also note its limits. Persistent serious violations by one party may erode the minimum level of mutuality required to maintain observance by others. Particularly in adversary relations between the superpowers, reasonable reciprocity in the use of force is a political necessity. But this should not become a game of tit-for-tat, in which violation by one allows a reciprocal violation by the other. The rules on use of force allow for legitimate responses to aggression; they do not permit reciprocal law-breaking.

A related argument is based on state conduct. Some commentators contend that the widespread and consistent violations of article 2(4) constitute practice sufficient to supersede the Charter rules and their customary law counterpart. ${ }^{76}$ This argument is no more convincing than the assertion that if a large number of rapes and murders are not punished, the criminal laws are supplanted and legal restraints disappear for everyone.

Although it is reasonably easy to determine when crimes such as murder have been committed, state conduct in the international field involves relatively few clear violations. Aggressive wars similar to the Nazi and Japanese invasions are rare. Most allegedly illegal uses of force arise out of armed interventions in situations involving charges and counter-charges of prior illegalities and aggressive intent. Certainly an impartial tribunal would find culpability in some of these cases. But we must remember that hundreds of political conflicts exist, and many if not most actions taken by states do not constitute illegal uses of force. Therefore, to conclude that some violations constitute "practice accepted as law" gives "prac-

peace and security. Measures taken by Members in the exercise of this right of selfdefence shall be immediately reported to the Security Council and shall not in any way affect the authority and responsibility of the Security Council under the present Charter to take at any time such action as it deems necessary in order to maintain or restore international peace and security.

75 U.N. Chiarter art. 35, para. 1.

${ }^{76}$ See, e.g., Franck, Who Killed Article 2(4)? or: Changing Norms Governing the Use of Force by States, 64 AM. J. INT'L L. 809 (1970); Rostow, supra note 70, at 287-88. 
tice" a peculiar meaning, quite different from "widespread and uniform" usage. Moreover, such violations as do occur are not "accepted as law." On the contrary, in virtually every case one state's use of force has been condemned by large numbers of states as violating existing fundamental law. ${ }^{77}$

This agreement on the rules' fundamental character takes us to the heart of the matter. When a principle is repeatedly and unanimously declared to be a basic legal rule from which no derogation is allowed, even numerous violations do not become state practice constitutive of a new rule. Contrary usage alone should not terminate a principle that states have strongly affirmed to be a condition necessary for order. Infringements of existing rules reflect expediency and political motives: it would make nonsense of customary law to treat them as repealing an accepted basic obligation. ${ }^{78}$ No state has ever suggested that violations of article 2(4) have opened the door to free use of force. Nor have international lawyers (with a few ambiguous exceptions) supported so radical a conclusion.

It is not my purpose here to argue that the Charter rules, or their customary law counterparts, are immutable. We cannot exclude the possibility that new configurations of power and altered psychological attitudes will wreak a fundamental change in the state system. Some envisage a single world authority, others a hegemonial condominium, and still others a basic shift of authority to non-territorial entities. If such a change occurs in one form or another, the rules governing force will change correspondingly. But with the existing balance of power and strong nationalist loyalties, the basic Charter principles themselves are unlikely to change. However, pressures for loosening the restraints on the use of force in some situations are likely to increase. They call for analysis.

\section{Necessary Self-Defense}

A. Limits on Defense

When states resort to armed force these days, they most commonly claim self-defense, either individual or collective, as their legal justification. Under the U.N. Charter it is clear that self-defense is legitimate "if an armed attack occurs." 79 The necessity of

77 See John Murphy, The Unted Nations and the Control of Violence 125-26 (1982); see also Edwin Hoyt, Law and Force in American Foreign Policy 19 (1985).

73 See C. DE VISSCHER, supra note 52, at 156-57.

79 U.N. Charter art. 51, quoted in full supra at note 74 . 
defense in this situation is taken for granted.

The question becomes more complicated when the armed attack has succeeded in seizing territory and some time has elapsed. Has a state a continuing right to self-defense to recover territory unlawfully taken by armed force? Once the emergency of an armed attack has ended, a victim of aggression can reasonably be required to seek and exhaust all avenues of peaceful settlement. But if such avenues prove futile, is self-defense then "necessary"?

I suggest that the idea of self-defense contains a temporal element. It refers to a response made close in time to an attack or imminent threat. Without that limitation, self-defense would sanction armed attacks for countless prior acts of aggression and conquest. It would completely swallow up the basic rule against using force. The difficulty of defining a precise time limit-a statute of limitations, as it were-does not impugn the basic idea. In most cases irredentist demands for lost territory or claims for restoration of the status quo ante are based on attacks that occurred many years or even decades ago. ${ }^{80}$ To extend self-defense to such cases is to stretch the notion of defense far beyond its basic meaning. ${ }^{81}$

An additional requirement of proportionality is linked to necessity: acts done in self-defense must not exceed in manner or aim the necessity provoking them. This definition leaves room for differences in particular cases but there is no mistaking its core meaning. Security Council decisions have condemned defensive action that greatly exceeded the provocation (as measured by scale of weaponry and relative casualties) as illegal reprisals rather than legitimate self-defense. ${ }^{82}$ It seems reasonable, however, to allow an attack victim to retaliate with force beyond the immediate area of attack when it has good reason to expect further attacks from the same source. Such action would not be merely "anticipatory" since prior attacks took place; nor would it be a reprisal inasmuch as its prime motive is protective, not punitive.

\section{B. Proposed Expansions}

The most controversial question is whether self-defense may extend to situations not involving armed attack. It has been argued

${ }^{80}$ For example, see the Argentine statement on its use of force in the Malvinas (Falkland Islands), 37 U.N. GAOR (51st meeting) at 7, U.N. Doc. A/37/353 (1982).

s1 See Schachter, supra note 5, at 1627-28.

${ }^{82}$ See Bowett, Reprisals Involving Recourse to Armed Force, 66 AM. J. INT'L L. 1, 3336 (1972). 
that Charter article 51 does not say that an armed attack is always required. Some scholars infer from this that the drafters of article 51 did not intend to impair the customary law "inherent right" of defense. ${ }^{83}$ Despite this ingenious argument, most commentators agree that article 51 defines and limits self-defense to cases of armed attack. ${ }^{84}$ To treat that phrase as only a "hypothesis" or an example of one aspect of self-defense does not make much sense of the text or the intent to impose limits on force.

Whatever the intended meaning of article 51, most U.N. members tend to favor the more restrictive interpretation. ${ }^{85}$ They fear that deletion of the armed attack requirement and reliance on an "inherent right" undefined in customary law would so expand selfdefense as to eliminate virtually all restraints on force. "Armed attack" is a factual, objective condition; it can generally be verified.

In contrast, the "inherent right" is open to subjective interpretation. Customary law offers few firm guidelines-understandably, since war itself was not considered illegal for many centuries. History abounds with examples of self-defense claims serving as pretexts for aggressive acts. For example, Germany and Japan contended that their military actions leading to World War II were defensive responses to actions by others aimed at denying them their rightful territorial and economic claims. ${ }^{86}$ The Nuremberg and Tokyo tribunals had no difficulty rejecting these arguments in light of the evidence on intent to dominate and expand. But the fact that self-defense could be claimed (and probably believed by many German and Japanese people) showed how important it was to limit and define the grounds for its exercise.

Accepting the need for limits on self-defense does not negate the contention that the armed attack requirement is too rigid. One may grant that the Charter restricts self-defense to cases of armed attack, yet conclude that a strict application of that requirement does not satisfy present perceptions of necessary defense. Several situations raise this issue:

ss See D. Bowetr, supra note 62, at 187-93; M. McDovgal \& F. Feliciano, Law and Minimum World Public ORder 232-44 (1961). But see H. KELSEN, supra note 62, at 58-62; see also L. HENKIN, supra note 50, at 141-45 (discussing the importance that the drafters of article 51 attached to the phrase "if an armed attack occurs").

s4 The International Law Commission, after a survey of writers in many countries, concluded that the majority favor the restrictive view. See Report of the International Law Commission to the General Assembly, U.N. Doc. A/35/10 (1980), reprinted in [1980] 2 Y.B. INT'L L. CoMm'N 52-53 \& nn.174-75, U.N. Doc. A/CN.4/SER.A/1980/Add.1/pt.2.

os See Rosalyn Higgins, The Development of International Law Through the Political Organs of the UNited Nations 167-230 (1963).

so See Judgment, supra note 3, at 191, 194, 206-15; S. HoRwiTz, supra note 3. 
1) Credible threats of force by hostile states;

2) "Indirect aggression"-instigating or aiding subversive and armed activities to overthrow the regime of another state;

3) Foreign state intervention in civil strife by providing arms and personnel to one side;

4) Terrorist activities against a state's nationals, especially seizure of hostages whom the territorial sovereign is unable or unwilling to protect. ${ }^{87}$

In each of these situations, the injured state may reasonably believe that non-forcible measures cannot provide adequate redress. Hence it will see armed force as necessary. Also, since the injured state may have insufficient military strength for self-defense, it probably will seek outside aid for collective self-defense. In this situation, states not themselves injured may also claim self-defense though no state suffered an actual armed attack.

To deal adequately with these situations would require far more space than this article allows. However, a brief summary of the considerations pertinent to each case may be of interest.

1. Threats of Force and Anticipatory Defense. The Nuremberg and Tokyo trials emphasized the significance of Germany's and Japan's planning and preparation for war. Many people today believe that the threatened powers and their allies could have prevented the war by defensive action. This line of reasoning suggests that anticipatory defense may be warranted against a state that credibly threatens war by stockpiling armaments and expressing hostile intent.

The Cuban missile crisis in 1962 presented a variant of this situation. The U.S. saw the installation of missiles in Cuba as a threat, and they responded with a blockade implicitly involving a use of force. Although the U.S. perceived its actions as a defensive response, it officially justified the blockade by pointing to an ex post facto "authorization" by the Organization of American States. ${ }^{88}$ By not asserting a legal self-defense claim, the U.S. sought to avoid a reciprocal claim that U.S. missile bases near the Soviet Union were unlawful and justified Soviet armed response.

On the other hand, Israel asserted self-defense when it destroyed an Iraqi nuclear reactor, citing Iraq's declared state of war

${ }^{87}$ This list of situations to which commentators propose extending the self-defense exception is not exhaustive, but illustrative. See Schachter, supra note 5, at 1633-45.

s8 See 4 Marjorie Whiteman, Digest of International LaW 523-24 (1965); see also Abram Chayes, The Cuban Missile Crisis 41-68 (1974); L. Henkin, supra note 50, at 22731. 
against Israel and the actual menace of a reactor capable of producing nuclear weapons. ${ }^{89}$ In the U.N. debates on this action, most states rejected Israel's contention because the reactor in question was devoted to peaceful uses and they viewed the possibility of its conversion to military use as only a remote threat to Israel. ${ }^{90}$ Interestingly, in the debates some delegates referred favorably to Daniel Webster's formulation in the Caroline case of a right to self-defense where an attack is imminent. In Webster's eloquent phrase, a state has a right to self-defense prior to an armed attack only when the "necessity of that self-defence is instant, overwhelming, and leaving no choice of means, and no moment for deliberation."11

Some hold that the Caroline principle still leaves too much latitude for a state to use force prior to an actual attack. ${ }^{22}$ Others fear that it takes inadequate account of a build-up of arms-especially nuclear missiles-that could on first strike destroy a victim's defensive capability. ${ }^{93}$ Both concerns are understandable. They reveal the inability of a general principle to capture the full dimensions of the problem of dangerous threats. We need specific legal regimes setting limits on force and providing means of verification. Some such regimes exist in treaties and by informal arrangements: these and future agreements may provide a blueprint for arms controls. ${ }^{94}$

* See D'Amato, Israel's Air Strike upon the Iraqi Nuclear Reactor, 77 AM. J. INT'L L. 584 (1983); Mallison \& Mallison, The Israeli Aerial Attack of June 7, 1981, Upon the Iraqi Nuclear Reactor: Aggression or Self-Defense? 15 Vand. J. Transnat'L L. 417, 435-37 (1982).

${ }^{\circ 0}$ See 36 U.N. SCOR (2285-88th mtg.) passim; U.N. Docs. S/P.V.2285-89 (1981).

21 John Bassett Moore, A Digest of International Law 412 (1906); see also CASEBooK, supra note 24, at 890-91.

22 See, e.g., L. HENkIN, supra note 50, at 141-45.

03 See, e.g., Wolfgang Friedmann, The Changing Structure of International Law 259-60 (1964); Schachter, supra note 5, at 1633-35; Singh, The Right of Self-Defence in Relation to the Use of Nuclear Weapons, 5 Indian Y.B. OF INT'L AfF. 3 (1956).

os Existing treaties include those limiting areas in which nuclear weapons can be employed, see, e.g., Treaty Banning Nuclear Weapon Tests in the Atmosphere, in Outer Space and Under Water, opened for signature Aug. 5, 1968, 14 U.S.T. 1313, T.I.A.S. 5433, 480 U.N.T.S. 43; Treaty on Principles Governing the Activities of States in the Exploration and Use of Outer Space, opened for signature Jan. 27, 1967, 18 U.S.T. 2410, T.I.A.S. 6347, 610 U.N.T.S. 205; those establishing regional nuclear-free zones, prohibiting proliferation, and limiting size and number of weapons, see, e.g., Treaty on the Non-Proliferation of Nuclear Weapons, opened for signature July 1, 1968, 21 U.S.T. 483, T.I.A.S. 6839, 729 U.N.T.S. 161; Treaty on the Limitation of Anti-Ballistic Missile Systems, May 26, 1972, United StatesU.S.S.R., 23 U.S.T. 3435, T.I.A.S. 7503; those providing for emergency communication and notification of dangerous situations (U.S.-U.S.S.R bilateral treaties); and those providing for international inspection of nuclear facilities (International Atomic Energy Agency). Future arrangements being considered in intergovernmental negotiations include exchanges of detailed military information, advance notification of military movements, reports on military expenditures, and measures for inspection and verification. Detailed proposals on these lines 
On the level of principle, it makes sense to support a norm that opposes the preemptive resort to force but acknowledges its necessity when an attack is so immediate and massive as to make it absurd to demand that the target state await the actual attack before taking defensive action. Webster's statement in the Caroline case is probably the only acceptable formulation at the present time to meet this situation.

2. Indirect Aggression. States generally agree that it violates article 2(4) to support armed activities or subversive infiltration to overthrow a regime in another state. The regime attacked may of course take armed action in its territory. May it also use force against the state supporting the hostile activities, and may third states attack that state as part of a collective defense arrangement? Should a line be drawn between support of armed activities and an armed attack within the meaning of article 51?

The latter issue arose in the Nicaragua-U.S. dispute. ${ }^{95}$ The U.S. contended that Nicaragua's provision of war matériel and technical aid to El Salvadoran insurgents constituted an armed attack on El Salvador, allowing that state and others to attack Nicaragua in collective self-defense. ${ }^{96}$ Nicaragua maintained that such aid-whether legal or not-fell short of an armed attack and consequently did not justify armed defense. ${ }^{97}$ More particularly, Nicaragua asserted that its aid did not legally warrant U.S. support through arms and training of the "contras" fighting against the Nicaraguan regime..$^{98}$

Although the U.N. has condemned indirect aggression as illegal, most states have been reluctant to label it as "aggression" within the definition adopted by the General Assembly in $1974 .{ }^{99}$ Extending the scope of "aggression," they fear, would expand the right of self-defense. Memories still remain of armed interventions

were made in 1985 by European governments and by the United States to the Conference on Confidence-Building and Disarmament established pursuant to the Helsinki Final Act of 1975. The draft Contadora agreement for Central America also includes provisions for limits and verification in regard to armaments.

95 At the time of writing, the International Court of Justice has not decided the Nicaragua-U.S. case. The positions of the two governments on the merits were indicated in the Court's Order of May 10, 1984, and more fully in Judge Schwebel's dissenting opinion. See Military and Paramilitary Activities in and against Nicaragua (Nicaragua v. U.S.), 1984 I.C.J. 169, 191-99 (Schwebel, J., dissenting).

${ }^{96} \mathrm{Id}$. at 191-92.

${ }^{87} I$ d. at $190-91,193$.

98 Id. at 170-72 (majority opinion); id. at 193 (Schwebel, J., dissenting).

${ }^{\text {* }}$ See Aggression Resolution, supra note 24. 
on the pretext of combating alleged illegal acts. ${ }^{100}$ On the other hand, when armed guerrillas are supported by an outside state, the aggrieved state may reasonably view that outside state as the source of an armed attack even if the latter's armed forces are not directly engaged. The aggrieved state's only effective defense may be collective military action against the indirect aggressor. It does not seem unreasonable to interpret "armed attack" to cover the indirect but substantial support of military action directed against a government. ${ }^{101}$ Accordingly it would not only be illegal for a state to finance insurgent movements or to allow its territory to be used for organizing and training armed opposition movements, but such tactics would open that state to an armed defensive action by or on behalf of the victim of the indirect aggression.

3. Intervention in Civil Strife. It is well established that a state acts illegally by sending armed forces or matériel to support an insurgency. If its action falls within the definition of armed attack, both the attacked state and its allies may employ armed defense against the intervening state. In short, counter-intervention in civil strife may be an exercise of collective self-defense.

These rules are universally accepted where the illegal intervention occurs on the side of the insurgency. In addition, many legal scholars (and some U.N. resolutions, by implication) support the proposition that direct or indirect armed intervention on either side in a civil war is illegal. ${ }^{102}$ Under article 2(4) intervention constitutes a use of force "against the political independence" of the state in question because it interferes with its people's right to determine their own political destiny. Consequently, collective selfdefense could allow a state to give military aid in a civil war if another foreign power is already giving military aid to the opposite side. ${ }^{103}$

On its view of the facts, Nicaragua could argue that these principles justify its "counter-intervention" in EI Salvador. The U.S., which takes the position that the Sandinista regime has illegally intervened in El Salvador, could claim a collective self-de-

${ }^{100}$ See E. HoYT, supra note 77 , at 19 (discussing various covert interventions by the United States and the Soviet Union since World War II).

${ }^{201}$ See Resolution on Non-Intervention, supra note 41; see also Law and Crvil War IN THE MODERN WorLd (J. Moore ed. 1974) (especially the essays by Moore and Bowett and the comments by Falk, Farer, and Sohn) [hereinafter cited as Crvil WAr].

102 See Resolution on Non-Intervention, supra note 41; see also Moore, Toward an Applied Theory for the Regulation of Intervention, and Bowett, The Interrelation of Theories of Intervention and Self-Defense, in CrviL WAR, supra note 101, at 26, 41-46.

10s See Schachter, supra note 5, at 1641-42. 
fense right to attack Nicaragua, directly or indirectly. This issue may be decided by the International Court of Justice in the case now before the court.

This position on defensive counter-intervention ignores the ideological stamp of the regime or insurgency involved in the conflict. The principle is neutral as between democratic and nondemocratic governments. However, one commentator argues that counter-intervention should only be permitted on the side of a party (whether government or insurgency) that supports self-determination and popular rule. ${ }^{104}$ In other words, counter-intervention based on collective self-defense should be in accord with the basic principles of the U.N. Charter and the Universal Declaration of Human Rights. ${ }^{105}$ Thus, collective self-defense would have a moral legitimacy beyond its role as a sanction against a prior illicit intervention.

Under this view, the initial intervention remains illegal but counter-intervention would be permissible against a party that violates principles of self-rule and human rights. However, such a rule would be very imprecise in application. Most governments facing popular revolt violate those principles, and the insurgents invariably assert their democratic aims. Thus, aid to insurgents, while illicit in theory, could be freely rendered since it could not be countered with aid to the repressive government. Conversely, insurgencies may be labeled "totalitarian" by unsympathetic observers. If that occurred, aid to insurgents could be attacked as illegal even if it would otherwise be justified as a counterintervention.

Adopting a standard based on the ideological position of a particular government or faction would create serious difficulties. Even the democracies of Europe often differ with the U.S. about the political tendency of any particular group. This indicates how difficult it would be to reach consensus on the legality of a counterintervention. The problematic nature of the inquiry should encourage us to pause before adopting such a test.

4. Terrorism and the Taking of Hostages. May a state whose nationals have been seized by terrorists and held as hostages, or threatened with death, use armed force to rescue them? This issue has been raised with increasing frequency as seizure of hostages becomes ever more the favorite tactic of terrorist groups. Generally speaking, a state has no right to invade a foreign state to rescue or

104 Cutler, supra note 50, at 106-09.

108 G.A. Res. 217, U.N. Doc. A/777 (1948). 
protect its nationals who are considered to be held unlawfully by that state or by private persons. ${ }^{106}$ This proposition also holds where a state fails to protect a foreign national from criminal acts or injuries by private persons in that country. A government may strongly protest a national's arbitrary detention or inhumane treatment in prison, but it must have recourse to available diplomatic and possibly judicial procedures. The government may also impose non-military sanctions on the state that shirked its obligations under international law.

In some situations, however, such as the Israeli hostages held at Entebbe Airport or the American hostages held in Tehran, when lives are in imminent danger, a good case exists for an exercise of self-defense through a rescue attempt. ${ }^{107}$ Such attempts must be limited to the rescue and must not serve as a basis for political pressure or reprisal.

A more controversial question concerns a state's use of force to apprehend alleged terrorists who are within another state's jurisdiction or control. This issue was raised dramatically in 1985. Four U.S. military planes intercepted an Egyptian aircraft flying over the Mediterranean Sea, compelling it to change course and land in

108 Restatement of the Foreign Relations Law of the United States (Revised) $\S \S 431-432$ (Tentative Draft 1985).

${ }^{107}$ In both the Entebbe and Iranian situations, the hostages were seized and held as part of a political action against the state of their nationality. The attack on the individuals was clearly meant as an attack on their government. The territorial state was unwilling to rescue them and in fact supported the seizure. The hostages were believed to be in imminent peril of death. On the Israeli mission to free the hostages at Entebbe, see Boyle, The Entebbe Hostages Crisis, 22 IndiAn J. INT'L L. 199 (1982), and Paust, Entebbe and SelfHelp: The Israeli Response to Terrorism, 2 Fletcher Forum 86 (1978).

On these facts, the U.S. representative at the U.N. Security Council debate advanced a legal justification for the Entebbe rescue action. He conceded that the rescue action violated Uganda's territorial integrity and would normally be illegal. But he went on to say:

[T] here is a well-established right to use limited force for the protection of one's own nationals from an imminent threat of injury or death in a situation where the state in whose territory they are located either is unwilling or unable to protect them. The right, flowing from the right of self-defense, is limited to such use of force as is necessary and appropriate to protect threatened nationals from injury.

Statement of Ambassador Scranton, 1976 Digest of United States Practice In InTernaTIONAL LAW 150-51.

This statement follows from Sir Humphrey Waldock's 1952 formulation of principles on the use of force. See Waldock, The Regulation of the Use of Force by Individual States in International Law, 81 REcukn DES Cours 451, 467 (1952). The stringent conditions for intervention are as follows: The action must be for rescue and protection, not punitive reprisal, and it must not intervene beyond its necessity; an action legal in its inception would become illegal if prolonged or used for political pressure. See Schachter, International Law in the Hostage Crisis: Implications for Future Cases, in American Hostages In Iran 325 (P. Kreisberg ed. 1985); see also Schachter, supra note 5, at 1631-32 (discussing the Grenada incident). 
Italy, so that the accused persons on board would be prosecuted for seizing an Italian vessel, taking hostages, and murdering an American passenger. The U.S. considered the action necessary because the alleged terrorists were presumably being taken to a destination where their offense would go unpunished.

Neither the President nor any senior U.S. official offered an explicit legal ground for the interception of the Egyptian plane. ${ }^{108}$ The implicit premise of the U.S. action appeared to be that any state (or at least any specially affected state) could use force to obtain custody of terrorists when the state having control of them was unwilling or unable to bring them before a court of justice. No one referred at the time to the possible relevance of either Charter article 2(4) or of rules in civil aviation treaties prohibiting interceptions of civilian aircraft over the high seas. ${ }^{109}$ The overriding consideration expressed by the President was that "there must be no asylum for terrorists or terrorism."

It might have been argued that Egypt had violated a new (or nascent) international obligation of all states to prosecute accused terrorists or takers of hostages or to extradite them to countries where they would be subject to prosecution. But even if that proposition were sustainable on the law and facts, it does not follow that another state may use or threaten force against a civilian plane outside that state's jurisdiction. That situation is clearly distinct from the seizure of a "pirate ship or aircraft" (or a ship seized by pirates and under their control). In the latter case, as long as the vessel or aircraft is on the high seas or anywhere else outside every state's jurisdiction, any state may take such action and arrest the wrongdoers on board. ${ }^{111}$ However, the fact that a state's vessel or plane is carrying "pirates" (or terrorists) and intends to release them does not transform the vessel or plane into a "pirate" ship or aircraft.

Strong public revulsion against terrorism has spurred increased demands for concerned states to deny all sanctuary to terrorists. Proposals have been made that the United States (and pre-

${ }^{108}$ See Terrorists Seize Cruise Ship in Mediterranean, 85 Dep'T St. Bult. 74-81 (Dec. 1985).

109 See Hailbronner, Freedom of the Air and the Convention on the Law of the Sea, 77 AM. J. INT'L L., 490, 513-19 (1983).

${ }^{110}$ White House Statement of October 9, 1985, reprinted in 85 DEP'T ST. BULL. 74 (Dec. 1985).

"11 U.N. Convention on the Law of the Sea, art. 105, U.N. Doc. A/CONF.62/122 (1982), reprinted in 21 I.L.M. 1261, 1289 (1981). This article repeats article 19 of the 1958 Convention on the High Seas and is declaratory of customary law. 
sumably any capable state) be permitted to seize accused terrorists from within states which fail to bring them to justice. Moreover, under these proposals every state could determine unilaterally its right to take action against a person it believes guilty. This of course represents a radical departure from the basic rule of territorial sovereignty. Thus one can safely predict that states generally will reject these proposals.

Such far-reaching revision of the rules may not even be necessary. The existing framework of law provides a remedy in the international conventions dealing with offenses related to terrorism. Each state party to those conventions undertakes to treat a terrorist offense as a serious crime, and either to prosecute the offenders itself or to extradite them to a state that will prosecute them. ${ }^{112}$ Obviously, these conventions do not solve the problem of non-cooperative states, and expecting such states to become parties to the conventions may be excessively hopeful. However, if the great majority of states become parties (as has happened in the cases of the conventions on hijacking and aerial sabotage), the pressures on a few recalcitrant states may prove effective. Underlying that assumption is the hope that states generally will perceive their common interest in punishing criminal acts that threaten all of them.

If these conventions prove ineffective, some countermeasures against the countries of refuge may be necessary. Suspension of air flights, trade and financial embargoes, and curtailment of travel rights are among the nonforcible measures available against a state which by support of or complicity with terrorists violates its international obligation toward all states. ${ }^{113}$

Recapitulation. In short, under existing law an armed attack is a basic condition of legitimate self-defense. That requirement may be reasonably construed to include both an imminent attack (as defined earlier) and indirect attacks. Unlawful acts that involve these uses of force, as well as direct attacks, give rise to the right to take forcible defensive action.

By and large, states profess adherence to the restrictive view

12 See, e.g., Convention for the Suppression of Unlawful Seizure of Aircraft (Hijacking), opened for signature Dec. 16, 1970, 22 U.S.T. 1641, T.I.A.S. No. 7192; International Convention Against the Taking of Hostages, G.A. Res. 34/146, U.N. Doc. A/C.6/34/ L.23 (1979), reprinted in 1979 U.N. JuRIDICAL Y.B. 124; see also Convention to Prevent and Punish Acts of Terrorism, opened for signature Feb. 2, 1971, 27 U.S.T. 3949, T.I.A.S. No. 8413 (adopted by the United States and six Latin American states in 1976).

${ }^{113}$ For example, see the recent U.N. General Assembly resolution on measures to prevent international terrorism, G.A. Res. 40/61, (Dec. 1985), and Security Council Resolution 579 (Dec. 1985) on international terrorism. 
of self-defense. They do not resort to force-or claim the right to such recourse-merely because a state has violated customary law or, for example, a treaty pertaining to treatment of nationals. Even when a state is labeled an "outlaw" for its gross or continuing breaches of clear rules of law, aggrieved states rarely assert a right to use force unilaterally, except in response to a prior use of force. Underlying this manifest reluctance of the community of states to legitimate forcible self-help is the conclusion, based on historical experience, that individual use of force is more likely in the end to jeopardize than to support the effort to obtain effective law.

\section{Justification of Force for Higher EndS}

The comments just made apply also to suggestions that individual states should be permitted to use force to achieve major political or moral ends. ${ }^{114}$ These suggestions fall within the conception of "just war" and resemble some of the classical efforts to place the legality of war on a moral plane. ${ }^{115}$ There are several variants of this general attitude but one is of particular interest today. It would allow force to be used when necessary to achieve selfdetermination, whether that involves freedom from foreign domination or freedom from repressive and tyrannical government. ${ }^{116}$ This position, it is interesting to observe, was once taken by spokesmen for newly independent and Third World states. They argued that wars of national liberation were not only legal under international law (a point generally conceded), but that other states had a right and even a duty to use force to assist the liberation effort. ${ }^{117}$ Western states contested this argument as violating the basic norms of non-intervention and non-use of force. ${ }^{118}$ More recently, U.S. writers who tend to be identified with conservative opinion have asserted that democratic states are entitled to use armed force to overthrow tyranny elsewhere and to bring about popular democratic rule. ${ }^{119}$

116 See J. STONE, supra note 36.

115 See, e.g., W. O'Brien, supra note 62, at 13-35; War, Morality and the Military Profession, supra note 62, at 237-487.

${ }^{116}$ See Reisman, Coercion and Self-Determination: Construing Charter Article 2(4), 78 AM. J. INT'L L. 642 (1984).

${ }^{117}$ See, e.g., Firmage, The "War of National Liberation" and the Third World, in Crvil WAR, supra note 101, at 317-23 (discussing Soviet and Chinese statements to this effect); see also Cohen, China and Intervention: Theory and Practice, id. at 376; Butler, Soviet Attitudes Toward Intervention, id. at 380-98.

${ }_{118}$ See, e.g., Schwebel, supra note 39, at 483-86.

11 See, e.g., Will, The Perils of Legality, NewsweEk, Feb. 27, 1984, at 84 
One international law scholar has declared that article 2(4) of the Charter is only a "means," which must yield to the higher purpose of self-rule. Self-determination in his view is the "key postulate of political legitimacy in the 20th century."120 A similar position has been articulated in the U.S. by commentators who supported the U.S. military action in Grenada. They assert that such action was legitimate because it was aimed at overthrowing a repressive government and bringing about democracy and freedom. Although this was not one of the stated legal justifications put forward by the U.S. government, many have considered it the real and better reason. ${ }^{121}$ Similar contentions are being made in favor of taking military steps to overthrow the non-democratic regime in Nicaragua.

This argument clearly appeals to the widespread sentiment that repressive and tyrannical regimes should be overthrown and that in many cases this "higher end" warrants the use of force. Moral reasons, whether based on utilitarian-welfare premises or the inherent dignity of human persons, have been advanced in support of that sentiment. ${ }^{122}$ From a legal standpoint, however, neither the U.N. Charter nor the extensive government commentary thereon supports an interpretation subordinating the basic prohibition against unilateral use of force to ends other than selfdefense or U.N. enforcement action.

Significantly, except for some oratorical flourishes, the U.S. has never claimed a right to intervene forcibly to bring about democratic government. In regard to Vietnam and, currently, Nicaragua, the United States has justified its intervention as a necessary response to illegal use of force and therefore as justified under the collective defense provision of article $5 .{ }^{123}$ In Grenada it presented other legal grounds but did not rely upon the right to introduce popular rule there or elsewhere. ${ }^{124}$ Whatever the merits of these various grounds, it is noteworthy that the U.S. has not declared that Charter article 2(4) may be suspended or ignored in the inter-

("[I]nternational law . . . is an intramural code, useful among nations that share common values but not germane to dealings with totalitarian or gangster regimes."); see also Kristol, International Law and International Lies, Wall St. J., June 21, 1985, at 26, col. 4.

120 Reisman, supra note 116 , at 643 .

${ }^{121}$ See, e.g., Kristol, supra note 119, at 26, col. 4.

${ }^{122}$ See N. PodHoretz, supra note 70, at 86-101.

${ }^{223}$ See Military and Paramilitary Activities in and Against Nicaragua (Nicar. v. U.S.), 1984 I.C.J. 169, 191-99 (Schwebel, J., dissenting) (presenting U.S. position on Nicaragua).

124 For the list of justifications offered by the United States, see supra note 29 and accompanying text. 
est of "higher" political goals. Nor for that matter has any other state.

The position of governments in this respect cannot be attributed to legalism or a desire to.pay rhetorical deference to the Charter. ${ }^{125}$ A more fundamental reason goes back to the point I stressed earlier-that it is incompatible with the concept of a pluralist society of independent states to allow states to attack each other in order to impose a particular form of government. It is no answer to this to maintain that force should be allowed only to bring about a goal, such as self-determination, which all states profess to accept. Nor is it an answer to say that the force used would be proportionate to the end. These justifications ignore the realities of a world deeply divided about the meaning of democracy and self-determination. Powerful states would be given a virtually unlimited right to overthrow governments alleged to be unresponsive to the "true" will of the people. One side's favored test of self-rule would not be acceptable to the other side. The weakness and politicization of collective institutions enhance the danger that ideological confrontation will turn into clashes of military force. Most responsible governments, I believe, recognize these dangers. They are not likely to "reinterpret" the Charter so as to increase those risks.

\section{Conclusion}

No one, it is safe to say, is satisfied with the present state of international law on the use of force. Only a raving optimist could expect a transformation in the foreseeable future to the system of enforceable law envisaged in the rhetoric of Nuremberg. We now realize that the bright line between aggression and defense, so clear in Nuremberg and Tokyo, can be blurred in conflicts over competing rights. Agreement on words, solemnly affirmed, has repeatedly dissolved under the pressure of divergent interests and perceptions. Neither governments nor their peoples are ready, by and large, to entrust their security and vital interest to foreign judges or international organs. The nation-state, whatever its deficiencies, represents for most peoples the primary source of identity and protection. The legacies of history and the long pre-civilized past have left a common "syndrome of parochialism"126 in which distrust of

${ }^{125}$ But see D'Amato, Nicaragua and International Law: The "Academic" and the "Real," 79 AM. J. INT'L L. 657, 662 (arguing that government justifications for interventions comport with academic versions of the law, even though their real reasons differ).

${ }^{128}$ Lasswell, Introduction: Universality Versus Parochialism, to M. McDougal \& F. 
strangers and expectations of violence contribute to a climate of mutual fear. In that climate armed defense, a felt necessity, carries with it the threat of offense. Clashes of interest or of ideology turn into covert or open tests of force. Rules of law are bound to appear fragile in the face of these realities.

Yet a stable society of sovereign states cannot exist if each is free to destroy the independence of another. Nor can we reasonably contemplate, in the present conditions of power, that either of the superpowers could impose its rule by coercion on the rest of the world or establish a condominium of shared authority over the globe. Their ruling elites are surely aware of the supreme risks to their survival in the event of a major clash of arms. The legal constraints on unilateral recourse to force reflect this reality. They are not solely the product of moral sentiment.

It is appropriate, of course, to point to the inadequacies of these constraints and the failures of the existing system. Perhaps it is time to "demand a miracle," as Richard Falk has suggested, ${ }^{127}$ and call for a truly global community that transcends the state system. I do not minimize the value of a vision of world order that looks beyond the present reality. "In dreams begin responsibilities," and it is not too soon to undertake the responsibilities of moving toward the dream of a demilitarized cooperative world society. But it is dangerous to cite the inadequacies of the present system as reasons for abandoning the basic restraints on the use of force. Neither the failures of the U.N. nor the violations of its Charter can justify a "realpolitik" that would allow states once again to wage war freely. It is foolish and perilous to conclude that infringements by some have, under principles of reciprocity, freed all from a rule so fundamental and essential to a stable world order. "Tit for tat" responses may help sustain some international rules, but to apply this approach to the basic rule on force is a path to anarchy.

That basic rule, as I have sought to show, is not simply an abstraction viewed as an ideal. It has evolved into a reasonably coherent set of principles and precepts derived from the Charter and a network of agreements. Much still remains to be done, but when we look back to Nuremberg and San Francisco in 1945, it is striking how the abstract notions of that time have been made concrete to cope with situations barely envisaged then. 
This process has also helped to counteract states' self-serving unilateral interpretations of the rules. For along with more specific rules have come collective judgments made inside and outside of international institutions. The states that have recourse to force cannot escape these judgments. To be sure, a nonbinding condemnation or rebuke does not have the enforceability of a judicial decision in a national court. But that is not to say that such critical judgments are without effect. Censure carries with it political costs. Those costs are not trivial, as shown by the intense efforts of governments to avoid censure and to demonstrate the legitimacy of their conduct. At times unilateralism may be tempting, especially for powerful states. The International Court of Justice may be defied by non-appearance. The condemnation of the General Assembly may be passed off with a quip. But in the end such unilateralism is bound to exact a steep price, by making it impossible to maintain the rules of co-existence necessary to avoid catastrophe. 